mice or a freshly opened corpse; uraemia produces a fishy ammoniacal smell; and diabetic coma an acetone odour like sweet apples or hay. (Incidentally the breath of the child with diphtheria was easily recognised by ward sisters in fever hospitals, and I once confirmed this in a small blind trial.)

Palliative measures for halitosis include breath sweeteners, peppermint, and spearmint. Mouthwashes and antibiotics upset the balance of micro-organisms and encourage resistant strains and moniliasis-so their prolonged use is inadvisable. Chlorophyll tablets have been promoted with the idea that they absorb odours, but there is no evidence of this. Mercifully halitosis is likely to disturb only those others who come into close contact with the sufferer-and those who have it are usually unaware and friends do not tell.

\section{Clifforo Hawkins}

Honorary Consultant Physician

The Postgraduate Centre,

Queen Elizabeth Hospital,

Birmingham B15 2TQ

1 Beary MD, Cobb JP. Solitary psychosis-three cases of monosymptomatic delusion of alimentary stench treated with behavioural psychotherapy. Br $\mathcal{F}$ Psychiatry 1981;138:64-6.

2 Davidson M, Mukherjee S. Progression of olfactory reference syndrome to mania: a case report. Am F Psychiatry 1982;139:1623-4.

3 Pryse-Phillips W. An olfactory reference syndrome. Acta Psychiatr Scand 1971;47:484-510.

4 Pitts G, Brogdon L Hu, Masurat T, Pianotti R, Schumann P. Mechanism of action of an antiseptic, anti-odor mouthwash. F Dent Res 1983;62:738-42.

Tonzetich J. Direct gas chromatographic analysis of sulphur compounds in mouth air Arch Oral Biol 1971;16:587-97.

McNamara TF, Alexander JF, Lee M. The rule of microorganisms in the production of oral malodor. Oral Surg Oral Med Oral Pathol 1972;34:41-8.

7 Sato H, Ohkushi T, Kaizu T, Tsunoda M, Sato T. A study of the mechanism of halitosis occurrence in periodontal patients. Bull Tokyo Med Dent Unit 1980;21:271-8.

Tonzetich J, McBridge BC. Characterization of volatile sulphur production by pathogenic and non-pathogenic strains of oral bacteroides. Arch Oral Biol 1981;26:963-9.

9 Kostelc JG, Preti G, Zelson PR, Brauner L, Baehni P. Oral odors in early experimental gingivitis J Periodont Res 1984;19:303-12.

10 Lovewell R. An unexpected cause of halitosis. Br Dent $\mathcal{F}$ 1984;157:384

11 Tydd TF, Dyer NH. Pyloric stenosis presenting with halitosis. Br Med $\mathcal{J}$ 1974; iii:321.

12 Bauman D. Halitosis from isosorbide dinitrate. $\mathcal{J} A M A$ 1975;234:482.

3 O'Reilly RA, Motley CH. Breath odor after disulfiram. FAMA 1977;238:2600.

14 Goldfrank LR, Howland MA, Kirstein RH. Arsenic. In: Goldfrank LR, Weissman RS, Flomenbaum NE, Howland MA, Lewin NA, Kulberg AG, eds. Goldfrank's toxocologic emergencies, 3rd ed. Connecticut: Appleton-Century-Crofts, 1986:609-15.

emergencies, 3rd ed. Connecticut: Appleton-Century-Crofts, 1986 .60
15 Silverstine CT. Garlic breath odor. Ohio State Med I 1936;32:1233.

16 James VI and I. A counterblast to tobacco. AD 1604. Minor works of King fames VI and I. Edinburgh: Scottish Text Society, 1982:98.

\section{When a woman asks for a caesarean section}

A woman has a clear right to refuse a caesarean section, and she is entitled to a full explanation of the circumstances before she gives or withholds consent. A more difficult question is how to respond when a labouring woman asks for a caesarean section that is not medically indicated. A recent American study explored this issue by presenting 112 obstetricians with various cases that included: a normal multigravida who had sued her last obstetrician; a multigravida at term with a baby in the breech position who was assumed to be acting altruistically for the baby; a woman in advanced labour who had had a previous caesarean section and was assumed to be trying to avoid the risk of uterine rupture. $^{1}$

Unfortunately the respondents were mainly university staff rather than private practitioners and so may not have been representative. Almost all, however, said that they would have refused operation to the normal woman despite her legal history. Most would have agreed on an operation for the woman at term with the baby in the breech position, but opinion was divided about the woman who had had a previous caesarean section. The article's authors applaud the "passive paternalism" of refusing an operation to the woman with no medical problems but champion the woman's right to operation "where alternate medically acceptable treatments exist."

The serious flaw in this argument is that vaginal delivery is a virtually inevitable consequence of being in labournot a medical treatment. Interference with this process by abdominal surgery requires a major medical indication. The authors argue that in the case of the woman with a baby in the breech position any risk to the fetus would probably be avoided by caesarean section, but this is inconsistent with the results of the Los Angeles controlled trial. ${ }^{2}$ In the case of the woman in advanced labour who had had a previous caesarean section they state that maternal risk would be reduced by operation. But the remote risk to the mother of scar rupture would be outweighed by the hazards of another caesarean section. Study of maternal mortality in England and Wales shows that in women whose pregnancies reach the stage of delivery both direct and indirect death rates are about 10 times higher when delivery is by caesarean section rather than vaginal. ${ }^{3}$ Some deaths are, of course, caused by the condition that was the indication for the operation, but at least half are caused by the speration itself. ${ }^{4}$ Lower case fatality rates in some American studies ${ }^{5}$ may be due partly to failure of ascertainment, ${ }^{4}$ partly to the absence of medical indications for some operations, and partly to a higher proportion of elective operations. Emergency caesarean sections lead to much more mortality ${ }^{3}{ }^{4}$ and morbidity ${ }^{7}$ than elective ones.

A labouring woman has the right to expect that her obstetrician will not exploit her natural fears, concerns, and discomfort to perform an operation for which there is no good medical indication when the mother and baby will do best by allowing labour to continue. Support and encouragement of women with problems in labour should be part of the stock in trade of the competent team of midwife and obstetrician.

The same ethical considerations apply for the doctor asked for an unnecessary caesarean section before labour begins. Elective caesarean section is relatively safer than emergency caesarean section for the mother but not for the fetus, with risks to respiratory function ${ }^{8}$ and intellectual development. ${ }^{9}$ To the immediate hazards of any caesarean section must be added the enhanced risk in a subsequent pregnancy of requiring another operative delivery ${ }^{10}$ or of developing placenta praevia. ${ }^{11}$ Fertility is also reduced. ${ }^{12}$

In southern Brazil half of private patients have caesarean sections, and operation rates are directly related to the woman's income and inversely related to her degree of risk. ${ }^{13}$ Women thus have caesarean sections when they can afford them rather than when they need them. This illustrates what may happen when doctors move away from medical indications.

\section{MARION H HALL}

Consultant in Obstetrics and Gynaecology,

Aberdeen Maternity Hospital,

Aberdeen AB9 2ZA

1 Johnson SR, Elkins TE, Strota $C$, Phelan JP. Obstetric decision-making: responses to patients who request caesarean delivery. Obstet Gynecol 1986;67:847-50.

2 Collea JV, Chein C, Quilligan EJ. The randomised management of term frank breech presentation: a study of 208 cases. Am $\mathcal{F}$ Obstet Gynecol 1980;137:235-42. 
3 Department of Health and Social Security. Report on confidential inquiries into maternal deaths in England and Wales 1979-1981. London: HMSO, 1986. (Report on health and social subjects No 29.)

4 Rubin GL, Paterson HB, Rochat RW, McCarthy BJ, Terry JS. Maternal death after cesarean section in Georgia. Am J Obstet Gynecol 1981;139:681-5.

5 Evrard JR, Gold EM. Cesarean section and maternal mortality in Rhode Island. Obstet Gynecol 1977;50:594-7.

6 Frigoletto FD, Ryan KJ, Philippe M. Maternal mortality rate associated with cesarean section: an appraisal. Am J Obstet Gynecol 1980;136:969-70.

7 Nielsen TF, Hokegard K-H. Postoperative cesarean section morbidity: a prospective study. Am $\mathcal{J}$ Obstet Gynecol 1983;146:911-6.

8 Olver RE. Impact of obstetric management on pulmonary function. In: Beard RW, Sharp F, eds.
Preterm labour and its consequences. London: Royal College of Obstetricians and Gynaecologists,

9 Ounsted M, Moar VA, Cockburn J, Redman CWG. Factors associated with the intellectual ability of children born to women with high risk pregnancies. BrMed f 1984;288: 1038-40.

10 Danforth DN. Cesarean section. JAMA 1985;253:811-8.

11 Singh PM, Rodriques C, Gupta AN. Placenta previa and previous cesarean section. Acta Obstet Gynecol Scand 1981;60:367-8.

12 Hemminki E, Graubard BI, Hoffman HJ, Mosher WD, Fetterly K. Cesarean section and subsequent fertility: results from the 1982 national survey of family growth. Fertil Steril 1985;43:250-8.

13 Barros FC, Vaughan JP, Victoria CG. Why so many caesarean sections? The need for a further poticy change in Brazil. Health Policy and Planning 1986;1:19-29.

\section{Time, gentlemen, please ...}

Next week will see the second reading in the House of Commons of a private member's bill to extend licensing hours so that pubs, clubs, and restaurants can sell alcohol from $1030 \mathrm{am}$ to $1130 \mathrm{pm}$. A bill has also been introduced into the House of Lords that would allow "any place where meals are served" (which would include designated rooms in pubs) to sell alcohol round the clock. Several previous attempts to extend licensing hours-including one by the former minister for health, Kenneth Clarke, in 1976-have failed, but this one may well succeed because it has government support. The pressure for change is almost wholly economic, and the drinks industry newspaper has estimated that the industry can expect increased profits of about $\$ 300 \mathrm{~m}$ annually if the hours are extended. ${ }^{1}$ The health issues have, as usual, been largely ignored.

It is extremely difficult to separate the effects of licensing on alcohol problems from the effects of price, advertising, and other factors. Alcohol researchers have leant towards the view that in societies as awash with alcohol as ours changes in licensing laws have little effect on alcohol related damage. This orthodox view was supported by at least one analysis of the changes in alcohol related harm after Scottish licensing laws were liberalised in $1976 .{ }^{2}$ Another analysis took a different view, however, and the truth is probably that any change that there might have been was obscured by changes in consumption caused by the recession and changes in police methods of dealing with drunks. ${ }^{3}$

To pick up what may be important effects caused by changes in licensing laws much more complex methods need to be applied on a smaller scale-and the opportunity for such a study arises only rarely. One did arise recently in North Carolina, and the researchers were unable to support the orthodox view and showed that a small change in licensing laws caused a statistically significant increase in deaths from drunken driving (Holt $\mathbf{H}$, International Group for Comparative Alcohol Studies, Poland, 1986). The chance arose in 1978 when 23 of the 100 counties in North Carolina for the first time allowed bars and restaurants to sell spirits to people on the premises whether or not they were eating. Previously neither bars nor restaurants had been allowed to sell spirits, but people had been able to take their own spirits i to a restaurant-a process called "brownbagging." The other 77 counties did not change and so provided excellent 5 controls. The researchers found a $6-7 \cdot 4 \%$ rise in spirit $\circ$ consumption and $16-24 \%$ increase in alcohol related traffic $\stackrel{\circ}{\circ}$ accidents in the counties that changed their laws and no such $\rho$ changes in the control counties. They also showed that $N$ buying alcohol in the bar or restaurant was more expensive $\overrightarrow{+}$ than taking it with you, and so in this case the small change in licensing has overridden the normally more powerful determinant of price.

I quote this study not to argue that it is directly applicable $\vec{\bullet}$ to the changes that are being proposed in England and Wales. but rather to illustrate that licensing changes can have powerful effects that may go unnoticed unless careful research is conducted. That changes in licensing law have $\bar{o}$ little effect on health is thus at best unproved; they may well have a serious effect.

What is not disputed-not even by the brewers-is $\overrightarrow{\overrightarrow{0}}$ that Britain has an immense alcohol problem. In such circumstances a government that cared about health would avoid changing the licensing laws, which is just what the suppressed report of the government think tank recommended. ${ }^{4}$ What such a hypothetical government would do to reduce alcohol problems would be to raise the real price of 3 . alcohol in the next budget.

Assistant editor,

RICHARD SMITH

Assis

1 Mosley P. Parliamentary action predicted. Flexihours next year. Morning Advertiser 1985 May 14. 2 Duffy JC, Plant MA. Scotland's liquor licensing changes: an assessment. $\mathrm{Br}$ Med $\mathcal{J}$ 1986:292:36-9.

3 Saunders $W$. Licensing law: the Scottish experience-a reply to Clayson. Action on $\mathbb{N}$ Alcohol Abuse Review 1985; July/August:3-14
A

4 Central Policy Review Staff. Alcohol policies in the United Kingdom. Stockholm: $\tilde{W}$ Stockholm University, 1982. 